\title{
PEMANFAATAN SISTEM INFORMASI PERIKANAN DALAM PENGELOLAAN SUMBERDAYA
}

\author{
Umar Tangke \\ Staf Pengajar FAPERTA UMMU-Ternate, e-mail: khakafart@yahoo.com
}

\begin{abstract}
ABSTRAK
Tantangan dalam pengembangan usaha perikanan di Indonesia adalah lemahnya sistem data dan informasi perikanan yang berpengaruh terhadap akurasinya dan ketepatan waktunya. Kelemahan ini dapat mengakibatkan salah perencanaan yang pada akhirnya bermuara pada kegagalan usaha. Sebagai negara kepulauan, Indoensia sudah seharusnya mempunyai Sistem Informasi Perikanan. Sistem informasi ini akan memberikan manfaat yang besar terutama didalam pemanfaatan sumberdaya perikanan secara berkelanjutan. Sistem informasi memiliki tiga elemen utama, yaitu data yang menyediakan informasi, prosedur yang memberitahu pengguna bagaimana mengoperasikan sistem informasi, dan orang-orang yang membuat produk, menyelesaikan masalah, membuat keputusan, dan menggunakan sistem informasi tersebut. Keterpaduan dari berbagai elemen sistem informasi perikanan secara sinergis akan memberikan atau menciptakan kondisi yang kondusif dalam pemanfaatan sumberdaya perikanan secara arif dan bijaksana dengan berpedoman pada aspek konservasi.
\end{abstract}

\section{Kata Kunci: Sistem Informasi Perikanan, Pengelaan Sumberdaya}

\section{Pendahuluan}

Indonesia merupakan negara kepulauan terbesar di dunia. Berdasarkan Konvensi PBB tentang Hukum Laut (UNCLOS) 1982, luas wilayah nasional 5,0 juta $\mathrm{km} 2$; terdiri dari 3,1 juta $\mathrm{km} 2$ perairan nasional dan luas daratan 1,9 juta km2, dan Zona Ekonomi Ekslusif (ZEE) 3,0 juta $\mathrm{km} 2$. Dalam luasan tersebut terdapat panjang garis pantai lebih kurang $81.000 \mathrm{~km}$ dan jumlah pulau-pulau kurang lebih 17.000. Dengan perkataan lain $62 \%$ adalah perairan nasional sedangkan $38 \%$ adalah daratan.

Di dalam laut yang begitu luas tersimpan sumberdaya kelautan yang dapat dibagi atas empat kelompok, (1) sumberdaya dapat pulih (renewable resources), (2) sumberdaya tidak dapat pulih (non-renewable resources), (3) energi kelautan, dan (4) jasa-jasa lingkungan kelautan (environmental services). Sumberdaya tak dapat pulih meliputi mineral, bahan tambang/galian, minyak bumi dan gas. Sumber energi terdiri dari OTEC (ocean thermal energy convertion), pasang surut, gelombang dan sebagainya. Sedangkan yang termasuk jasa-jasa lingkungan kelautan adalah pariwisata dan perhubungan laut. Potensi sumberdaya kelautan ini belum banyak yang digarap secara optimal karena informasinya belum ditempatkan dalam suatu sistem basis data yang terpadu sehingga menyulitkan dalam pencahariannya.

Sumberdaya dapat pulih terdiri dari sumberdaya perikanan tangkap dan sumberdaya perikanan budidaya (pantai/tambak dan laut). Berdasarkan hasil kajian KOMNAS KAJIS KANLAUT (1998) bahwa potensi lestari sumberdaya perikanan Indonesia sebesar 6,26 juta ton per tahun, terdiri dari ikan pelagis besar (975,05 ribu ton), ikan pelagis kecil $(3,235,50$ ribu ton), ikan demersal (1.786,35 ribu ton), ikan karang konsumsi (63,99 ribu ton), udang peneid (74,00 ribu ton), lobster (4,80 ribu ton), dan cumi-cumi (28,25 ribu ton). Dari potensi tersebut sampai pada tahun 1998 baru dimanfaatkan sekitar 58,5 persen. Bila tingkat pemanfaatan maksimum dimungkinkan sampai $90 \%$, berarti masih tersedia peluang pengembangan sebesar $31,20 \%$ dari potensi sumberdaya atau sebesar 1,95 juta ton per tahun.

Selain potensi perikanan tangkap, potensi lain yang dapat dioptimalkan adalah perikanan budidaya, baik budidaya pantai (tambak) maupun budidaya laut. Dengan kondisi pantai yang landai, kawasan pesisir Indonesia memiliki potensi sumberdaya pantai (tambak) sekitar 
830.200 ha yang tersebar di seluruh wilayah tanah air dan baru dimanfaatkan untuk budidaya (ikan banden dan udang windu) sekitar 356.308 ha (Dahuri, et al., 1996). Sementara itu, potensi pengembangan budidaya laut untuk berbagai jenis ikan (kerapu, kakap, beronang, dan lainlain), kerang-kerangan dan rumput laut, yaitu masing-masing 3,1 juta ha, 971.000 ha, dan 26.700 ha. Sedangkan potensi produksi budidaya ikan , kerang-kerangan dan rumput laut adalah 46.000 ton per tahun dan 482.400 ton per tahun. Secara keseluruhan potensi perikanan budidaya laut tersebut yang baru direalisasikan sekitar 35\% (Dirjen Perikanan, 1997 dalam Dahuri, 2000). Untuk memanfaatkan potensi perikanan budidaya tersebut perlu diciptakan suatu sistem informasi perikanan sehingga pengguna dapat mengakses dan memanfaatkannya secara lebih efisien dan efektif.

Salah satu sifat sumberdaya ikan adalah sangat dinamis yang dapat berubah dengan cepat sesuai dengan ruang dan waktu dan dengan kondisi lautan yang sangat luas, maka untuk pengelolaan sumberdaya ikan diperlukan informasi yang lebih spesifik baik secara temporal maupun secara spasial. Masih banyak informasi mengenai sumberdaya perikanan yang belum tersedia misalnya dimana ikan berada, kapan, jenis apa saja, berapa banyak, daerah mana yang belum dimanfaatkan, bagaimana pengaruh kondisi oseanografi terhadap sumberdaya dan sebagainya.

Melihat potensi perikanan yang begitu besar maka diperlukan adanya upaya pengelolaan dalam kegiatan pemanfaatan sumberdaya perikanan. Upaya tersebut diharapkan dapat membantu nelayan dan pengguna lain (stakeholder) untuk meningkatkan hasil tangkapan dan produksi budidaya dengan tidak mengganggu potensi kelestarian sumberdaya di perairan serta menghindari terjadinya kerusakan stok sumberdaya perikanan seperti penangkapan berlebihan (overfishing) dan mencegah sedini mungkin penangkapan ikan dengan menggunakan alat dan bahan yang bersifat merusak, seperti penangkapan ikan karang dengan alat muroami dan penggunaan potasium dalam penangkapan ikan-ikan karang, karena cara penangkapan yang demikian dapat berdampak terhadap kerusakan lingkungan.

Pengelolaan sumberdaya perikanan secara bertanggung jawab dapat dilakukan melalui suatu sistem informasi. Informasi tersebut akan menjadi bahan dasar dalam usaha memperoleh gambaran tentang kondisi sumberdaya yang terdapat di perairan secara kuantitatif dan kualitatif. Informasi sumberdaya dalam bentuk kuantitatif sangat ditentukan oleh ada-tidaknya data dasar seperti data hasil tangkapan, upaya tangkap, musim penangkapan dan penyebaran dari setiap sumberdaya perikanan.

\section{Tinjauan Aksiologi Sistem Informasi Perikanan}

Sebuah sistem informasi yang terintegrasi, sebagai realisasi akan adanya kebutuhan suatu sistem pemantau, harus dibangun untuk memenuhi kebutuhan yang semakin meningkat. Sistem ini yang dinamakan Sistem Informasi Perikanan mempunyai kegunaan antara lain:

a) Mendukung terciptanya suasana sinergis antara sistem-sistem informasi yang berkaitan dengan perikanan baik yang sudah ada, yang sedang dikembangkan, maupun yang sedang direncanakan.

b) Menekan pemborosan akibat adanya duplikasi data yang berkaitan dengan perikanan, sekaligus menjadi saling melengkapinya.

c) Menciptakan suatu sistem pendataan yang efisien dan sederhana hingga mudah dimengerti oleh berbagai pihak.

d) Mengsyaratkan data-data yang berkaitan dengan perikanan sehingga mudah dijangkau oleh seluruh lapisan masyarakat maupun instansi yang memerlukan.

e) Menyediakan data-data yang berkaitan dengan perikanan secara cepat.

f) Mendidik masyarakat untuk dapat mengerti karakteristik perikanan Indonesia.

g) Menciptakan rasa kepemilikan yang bertanggung jawab terhadap perikanan Indonesia pada masyarakat Indonesia secara umum.

h) Menyediakan informasi yang dibutuhkan secara lebih valid dan lengkap untuk menjadikan kebijakan lebih efektif.

Keuntungan yang diperoleh dari ketersediaan sistem informasi perikanan dapat dilihat dari 3 (tiga) sisi yaitu sebagai pemberi data, sebagai pengambil keputusan, dan sebagai pengguna informasi. Dari sisi pemberi data keuntungan diperoleh dengan adanya pemanfaatan data yang lebih optimal dan peluang menjual informasi dengan dimensi lebih luas. Sisi pengambil keputusan memperoleh manfaat di dalam peningkatan pelayanan, pengambilan keputusan yang lebih cepat dan tepat, maupun 
kebijakan-kebijakan yang akan lebih efektif dan efisien. Sedangkan dari sisi pengguna informasi nilai tambah ada pada berkurangnya risiko atas tindakan yang tidak tepat, meningkatnya daya saing, dan meningkatnya keuntungan.

\section{Sistem Informasi Perikanan}

\subsection{Pengertian Sistem Informasi}

Sistem adalah kumpulan elemen yang berintegrasi untuk mencapai tujuan tertentu, sedangkan informasi adalah data yang telah diolah menjadi bentuk yang lebih berarti bagi penerimanya dan bermanfaat dalam mengambil keputusan saat ini atau mendatang (Davis, 1999). Informasi dapat menggambarkan kejadian nyata yang digunakan untuk pengambilan keputusan. Sumber dari informasi adalah data yang dapat berbentuk huruf, simbol, alfabet dan lain sebagainya.

Sistem informasi memiliki tiga elemen utama, yaitu data yang menyediakan informasi, prosedur yang memberitahu pengguna bagaimana mengoperasikan sistem informasi, dan orangorang yang membuat produk, menyelesaikan masalah, membuat keputusan, dan menggunakan sistem informasi tersebut. Orang-orang dalam sistem informasi membuat prosedur untuk mengolah dan memanipulasi data sehingga menghasilkan informasi dan menyebarkan informasi tersebut ke lingkungan.

Model dasar sistem adalah masukan, pengolahan, dan pengeluaran. Fungsi pengolahan informasi sering membutuhkan data yang telah dikumpulkan dan diolah dalam waktu periode sebelumnya. Oleh karena itu pada model sistem informasi ditambahkan pula media penyimpan data (data base) maka fungsi pengolahan informasi bukan lagi mengubah data menjadi informasi tetapi juga menyimpan data untuk penggunaan lanjutan.

Model dasar ini berguna dalam memahami bukan saja keseluruhan sistem pengolahan informasi, tetapi juga untuk penerapan pengolahan informasi secara tersendiri. Setiap penerapan dapat dianalisis menjadi masukan, penyimpanan, pengolahan dan keluaran.

Keberhasilan suatu sistem informasi sangat bergantung pada sistem basis data. Semakin lengkap, akurat dan mudah dalam menampilkan kembali data yang ada dalam sistem basis data maka akan semakin tinggi kualitas sistem informasi tersebut.

Basis data (database) merupakan kumpulan dari data yang saling berhubungan satu dengan lainnya, tersimpan di perangkat keras komputer dan digunakan perangkat lunak untuk memanipulasinya. Data perlu disimpan di dalam basis data untuk keperluan penyediaan informasi lebih lanjut. Dengan ditambahkannya penyimpanan data, fungsi pengolahan infomasi bukan lagi mengubah data menjadi informasi tetapi juga menyimpan data untuk penggunaan lanjutan (Jogiyanto, 1999).

\subsection{Pengertian Perikanan}

Perikanan didefinisikan sebagai suatu kegiatan ekonomi dalam bidang penangkapan atau budidaya hewan atau tanaman air yang hidup bebas di laut atau perairan umum. Secara umum, perikanan dibagi atas perikanan tangkap dan perikanan budidaya. Perikanan tangkap adalah kegiatan ekonomi yang mencakup penangkapan atau pengumpulan hewan dan tanaman air yang hidup di laut atau perairan umum secara bebas sedangkan perikanan budidaya adalah kegiatan ekonomi yang mencakup pembudidayaan hewan dan tanaman air yang hidup di laut atau perairan umum.

\section{Pemanfaatan Sistem Informasi Dalam Pengelolaan Perikanan}

\subsection{Tantangan dan Permasalahan}

Dengan terbuka peluang permintaan terhadap produksi perikanan Indonesia, maka tuntutan untuk meningkatkan produksi perikanan juga akan semakin meningkat. Sayangnya dalam berbagai hal, terdapat permasalahan yang dihadapi khususnya dalam menerapkan pemanfaatan sumberdaya perikanan secara berkelanjutan. Oleh karena itu untuk memenuhi permintaan tersebut maka tantangan utama yang dihadapi oleh bangsa Indonesia dalam pembangunan perikanan adalah: (1) Peningkatan kualitas SDM perikanan dan penguasaan IPTEK untuk mendukung peningkatan produksi; (2) Pengembangan teknologi perikanan yang berwawasan lingkungan sebagai upaya untuk menjaga kualitas produksi dan kualitas lingkungan; dan (3) Menjaga dan mengamankan keberlanjutan sumberdaya perikanan baik dari ancaman pencurian maupun over-eksploitasi sumberdaya yang berlebihan.

Tantangan dalam pengembangan usaha perikanan di Indonesia adalah lemahnya sistem data dan informasi perikanan yang berpengaruh terhadap akurasinya dan ketepatan waktunya. Kelemahan ini dapat mengakibatkan salah perencanaan yang pada akhirnya bermuara pada kegagalan usaha, sehingga dimata para bankers usaha perikanan dianggap berisiko pada masa 
lalu padahal sumberdaya perikanan masih belum banyak yang digali. Namun pada masa sekarang dimana sumberdaya tersebut telah dimanfaatkan dan keadaan lingkungan yang semakin memburuk ketepatan data dan timingnya menjadi sangat menentukan.

Tantangan lain adalah kualitas sumberdaya manusia. Untuk membangun suatu sistem informasi dibutuhkan sumberdaya manusia yang berkualitas yang mampu menguasai teknologi sistem informasi dan mengoperasikannya dirasakan sangat rendah / sedikit bahkan mungkin tidak ada samasekali di daerah-daerah tertentu yang potensi perikanannya melimpah.

Salah satu permasalahan pembangunan perikanan Indonesia adalah keterbatasan data dan informasi yang dapat dijadikan rujukan perencanaan dan pengelolaan sumberdaya perikanan. Ketersediaan data dan informasi perikanan yang akurat hingga saat ini masih dipandang sebagai hal yang tidak begitu penting dan mendesak dalam pembangunan perikanan nasional. Hingga saat ini, belum ada lembaga yang menangani penyediaan data dan informasi secara menyeluruh, melainkan masih dilakukan oleh masing-masing instansi sesuai dengan kebutuhan. Akibatnya sering terjadi perbedaan data dan informasi perikanan. Sebagai contoh dalam perhitungan potensi lestari perikanan nasional hingga saat ini masih terdapat perbedaan. Padahal ketersediaan data dan informasi perikanan yang akurat merupakan faktor penting dalam penyususnan perencanaan dan pengelolaan sumberdaya perikanan, khususnya dalam merencanakan pembangunan perikanan yang optimal dan berkelanjutan, serta menghindari terjadinya over-eksploitasi sumberdaya perikanan.

Suatu sistem informasi yang bersifat lintas sektor mempunyai suatu beban yang berat yaitu bagaimana menyelaraskan seluruh instansi agar tidak ada yang merasa dirugikan, bahkan seluruhnya diharapkan mempunyai inisiatif untuk bergabung demi tercapainya sistem informasi menyeluruh yang handal.

Kendala dalam pengimplementasian sistem informasi yang terintegrasi adalah keberagamannya macam sistem yang telah ada sejak lama yang tersebar di berbagai instansi baik pemerintah maupun swasta, baik sipil maupun militer, baik di daerah maupun di pusat. Keberagaman ini bertambah parah dikarenakan pada kenyataannya tidak seluruh peralatan penunjang pengumpul data bekerja penuh secara elektronik, akan tetapi masih banyak pula yang semi-elektronik dan bahkan non-elektronik, sehingga hal ini benar-benar akan menimbulkan kesulitan di dalam pengintegrasiannya nanti. Jika semua peralatan harus diubah menjadi elektronik secara keseluruhan sesuai dengan tuntutan jaman informasi, maka salah satu kendala yang utama adalah mahalnya harga peralatan elektronik tersebut yang rata-rata memang masih merupakan barang impor. Hal ini mendorong kemadirian didalam peralatan-peralatan ini sudah mutlak diperlukan.

\subsection{Data dan Informasi Yang Diperlukan}

Hingga saat ini informasi tentang perikanan Indonesia diperoleh dari berbagai sumber informasi baik merupakan instansi pemerintah, swasta dan masyarakat. Instansi pemerintah yang dapat memberikan informasi tentang perikanan adalah departemen dan nondepartemen. Departemen yang langsung berhubungan dengan perikanan adalah Departemen Kelautan dan Perikanan dan Dinasdinas Perikanan di daerah, sementara departemen lain yang secara tidak langsung berhubungan dengan informasi perikanan adalah Departemen Perindustrian dan Perdagangan, Departemen Perhubungan, Departemen Tenaga Kerja, Departemen Keuangan, Departemen Luar Negeri, Departemen Pertahanan dan Keamanan/Polri dan Departemen Hukum dan Perundang-Undangan. Sedangkan instansi non-departemen yang secara tidak langsung juga berhubungan dengan perikanan adalah lembaga-lembaga penelitian dan pengkajian seperti BPPT, LIPI, BAKOSURTANAL, dan LAPAN, serta Universitas-Universitas.

Dari pihak swasta, informasi perikanan dapat diperoleh dari perusahaan-perusahaan atau industri-industri yang bergerak dalam bidang perikanan. Di Indonesia perusahaan-perusahaan atau industri-indutri ini sangat banyak dan bervariasi serta tersebar di seluruh wilayah Indonesia. Mereka mempunyai kantor-kantor perwakilan di daerah-daerah.

Dari pihak masyarakat, informasi perikanan dapat diperoleh dari koperasi-koperasi unit desa (KUD) yang berusaha dalam bidang perikanan. Mereka ini berada dalam jumlah yang banyak dan tersebar di daerah-daerah yang mempunyai potensi perikanan. Disamping itu terdapat juga lembaga-lembaga sosial masyarakat (LSM) yang berusaha di bidang Perikanan.

Bila dilihat dari jalur infomasi perikanan dari daerah sampai ke pusat, secara fungsional 
sistim informasi perikanan Indonesia dibagi menjadi 3 (tiga) bagian. Di tingkat pusat, Departemen Kelautan dan Perikanan (DKP) hanya berfungsi sebagai koordinasi, sedangkan di tingkat provinsi dapat bersifat melakukan monitor, dan di tingkat kabupaten/kota dan kecamatan bersifat aktif. Di tingkat kecamatan atau kota/kabupaten pembangunan Tempat Pelelangan Ikan (TPI) dengan fasilitasnya dibangun. Di tingkat pusat sendiri, DKP juga merupakan salah satu bagian dari jaringan informasi perikanan yang nantinya diharapkan dapat bersifat koordinatif terhadap sistem-sistem lain yang ada pada jaringan tersebut. Seperti pada perguruan-perguruan tinggi, pusat-pusat penelitian, lembaga-lembaga pemerintah nondepartemen, LSM-LSM, dan lain-lain.

Pembentukan sistem informsi perikanan memerlukan informasi perikanan. Informasi perikanan yang diperlukan dikelompokkan dalam informasi perikanan tangkap dan informasi perikanan budidaya. Informasi perikanan tangkap yang diperlukan meliputi: (1) distribusi spasial dan temporal jenis-jenis sumberdaya perikanan, (2) potensi lestari setiap jenis sumberdaya perikanan, (3) persyaratan ekologis bagi kehidupan dan pertumbuhan setiap jenis sumberdaya perikanan, (4) trophodynamics (transfer energi dan materi antar trophic level) dalam suatu ekosistem perairan dimana sumberdaya perikanan yang dikelola hidup, (5) dinamika populasi sumberdaya perikanan, (6) sejarah hidup dari sumberdaya perikanan, (7) kualitas perairan dimana sumberdaya hidup, dan (8) tingkat penangkapan/pemanfaatan terhadap sumberdaya perikanan, dalam bentuk upaya tangkap secara berkala. (9) Jumlah armada penangkapan ikan dari berbagai ukuran baik yang artisanal maupun modern secara spasial dan temporal serta jumlah nelayan yang memang benar-benar melakukan kegiatan sebagai nelayan.

Sementara kegiatan perikanan budidaya merupakan kegiatan pemanfaatan dan pengelolaan lingkungan perairan untuk membesarkan biota air (hewan maupun nabati) secara optimal. Agar kegiatan perikanan budidaya dapat berkelanjutan maka pemilihan lokasi harus dilakukan secara benar dan kegiatan/proses produksi hendaknya dilakukan menurut kaidah-kaidah ekologis dan ekonomis. Secara garis besar informasi utama yang diperlukan pada saat pemilihan lokasi adalah tentang kondisi biofisik (dari mulai kuantitas dan kualitas air, topografi, jenis tanah), pemilihan benih dan kondisi iklim. Sementara pada proses produksi, selain aspek lain yang menyangkut nutrisi, hama dan penyekit, genetika, pertumbuhan, dan interaksi ekologis biota yang dibudidayakan serta kualitas air, juga konversi pakan yang ditambahkan menjadi limbah yang terbuang ke perairan umum.

Dalam upaya mendapat sistem informasi perikanan yang terpadu, sistem informasi perikanan dikembangkan dengan konsep sebagai berikut:

1) Sistem informasi perikanan dikembangkan secara bertahap dan berkelanjutan.

2) Mendayagunakan sistem-sistem yang sudah ada - baik sistem informasi maupun sistem komunikasi secara maksimal.

3) Dalam langkah pendayagunaan tersebut, maka usaha intervensi dan atau modifikasi sistem informasi yang telah ada ditekan seminimal mungkin.

4) Pemanfaatan teknologi-teknologi mutakhir, yang cocok dengan spesifikasi di atas.

Sistem informasi perikanan pada dasarnya berfungsi sebagai sebuah infrastruktur informasi yang dapat digunakan untuk memecahkan berbagai permasalahan yang ada dan mengakomodir semua tujuan yang diharapkan. Sistem ini diharapkan dapat memberikan informasi yang berbasis multimedia kepada penggunanya. Sebagai contoh dapat dilihat pada Gambar 1 tentang bagan alir sistem informasi manajemen perikanan tangkap.

Pada Gambar 1. dapat dilihat bahwa suatu sumberdaya perikanan tangkap pada kabupaten dapat dikelola dengan baik jika melewati beberapa tahap dimana untuk data awal dalam pengelolaan dibutuhkan data citra dan tambahan yang berasal dari LAPAN, DKP, TNI-AL, Universitas, dan lain-lain dimana data tersebut dapat berupa peta digital, data potensi, data perikanan tangkap serta data lainnya, yang kemudian data ini diolah pada DKP kabupaten melalui suatu proses dengan memanfaatkan softwere yang dapat dipercaya kehandalannya, pada proses ini dengan menggunakan analisisanalisis terhadap semua variable diantaranya citra, factor oseanograi, potensi SDI, dan lainnya. Hasil analisis selanjutnya dimanfaatkan oleh user yaitu nelayan dan perusahaan penangkapan, dimana output data ini dapat berupa peta DPI, citra satelit dan laporan. Output selanjutnya akan dievaluasi untuk melihat kesalahan-kesalahan 
yang terjadi dimana jika terjadi kesalahan pada analisis, maka akan dilakukan proses pengolahan pada DKP kabupaten dan jika terjadi kesalahan pada proses awal maka dilakukan evaluasi ulang terhadap data awal sebagai dasar sumber informasinya. Selanjutnya dari hasil evaluasi maka dilakukan pengembangan untuk perbaikan di masa yang akan dating sehingga proses ini akan berjalan untuk optimalisasi pemanfaatan sumberdaya perikanan tangkap.

Sesuai dengan tujuannya, prinsip pengembangan sistem informasi perikanan adalah (1) mengembangkan dan menyatukan sistem informasi tentang perikanan yang sudah ada menjadi sebuah sistem "network" perikanan, (2) mendisain dan membangun sistem informasi yang belum tersedia kemudian menyambungkannya dalam sistem network perikanan, (3) mendisain dan membangun pusatpusat pelayanan data informasi, dan (4) merekayasa sebuah "protokol" bagi sistem "network" perikanan.
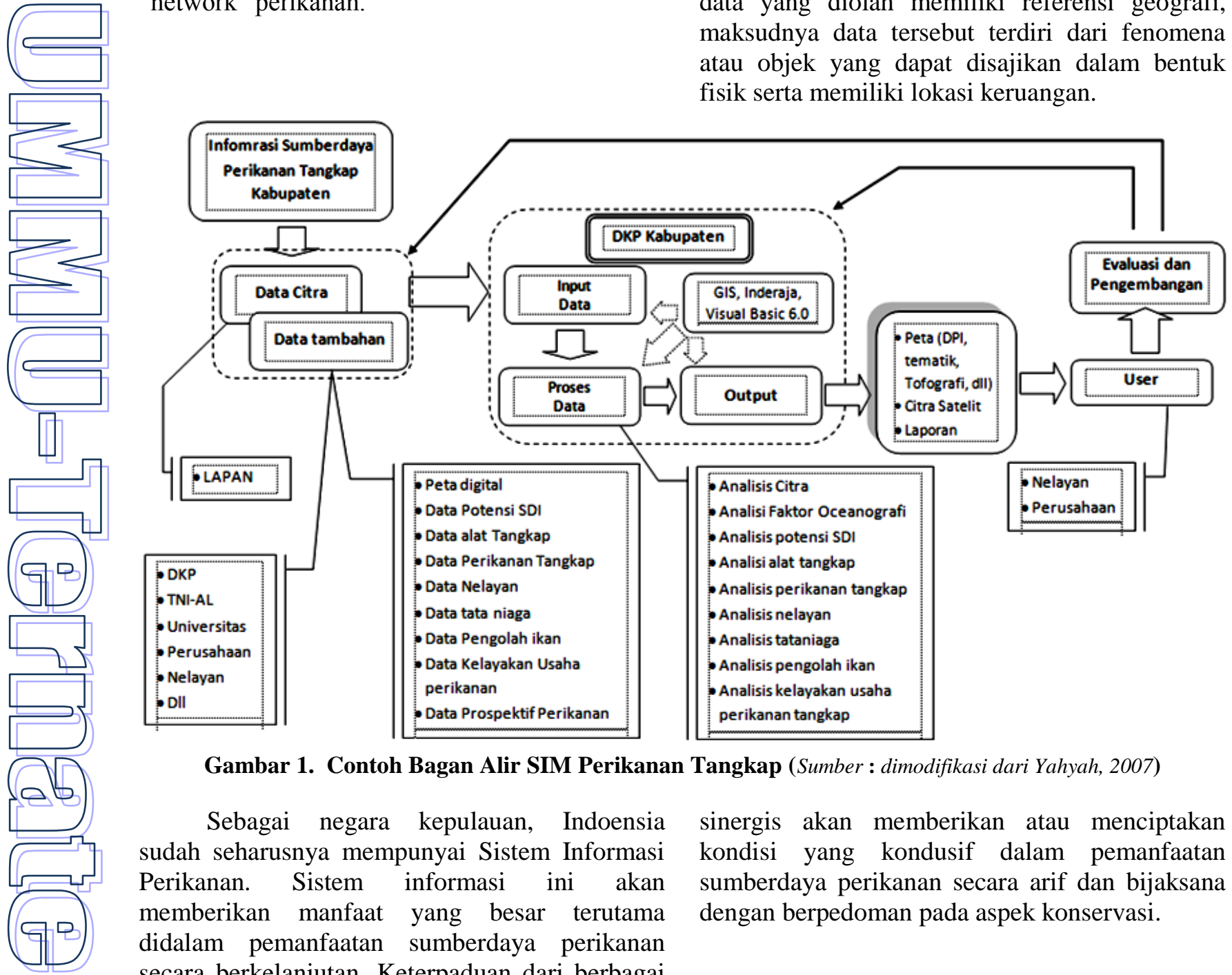

Gambar 1. Contoh Bagan Alir SIM Perikanan Tangkap (Sumber : dimodifikasi dari Yahyah, 2007)

Sebagai negara kepulauan, Indoensia sudah seharusnya mempunyai Sistem Informasi Perikanan. Sistem informasi ini akan memberikan manfaat yang besar terutama didalam pemanfaatan sumberdaya perikanan secara berkelanjutan. Keterpaduan dari berbagai elemen sistem informasi perikanan secara

\section{Penutup}

Potensi sumberdaya perikanan, merupakan salah satu komoditas unggulan yang harus dikelola secara baik dan arif. Oleh karena diperlukan perencanaan Sistim Informasi manajemen pengelolaan dan pembangunan Sistim informasi manajemen pengelolaan untuk pemanfaatan berkelanjutan sehingga sumberdaya perikanan dapat terjaga kelestariannya.

Salah satu contoh penggunaan perangkat lunak dalam sistem informasi manajemen yaitu Sistem Informasi Geografi (SIG) dimana sistem informasi ini dirancang untuk bekerja dengan data yang bereferensi spasial atau berkoordinat geografi atau dengan kata lain suatu SIG adalah suatu sistem basis data dengan kemampuan khusus untuk menangani data yang bereferensi keruangan (spasial) bersamaan dengan seperangkat operasi kerja (Barus dan Wiradisastra, 2000). Aplikasi SIG dapat digunakan untuk berbagai kepentingan selama data yang diolah memiliki referensi geografi, maksudnya data tersebut terdiri dari fenomena atau objek yang dapat disajikan dalam bentuk fisik serta memiliki lokasi keruangan. 
Di era otonomisasi, sistem informasi perikanan akan memberikan dampak yang positf bagi pembangunan daerah. Sistim informasi perikanan daerah akan disempurnakan dengan berbagai informasi dari sumber lain yang sehingga daerah dapat melakukan perencanaan dan pengelolaan potensi sumberdaya perikanan secara terpadu dan berkelanjutan. Oleh karena itu kerjasama antara pemerintah, masyarakat dan akademisi baik ditingkat pusat maupun di daerah perlu ditumbuhkembangkan. Kondisi ini akan memicu tumbuhnya rasa kepedulian terhadap perikanan.

Pengembangan data dan informasi sebagai bahan perencanaan pembangunan perikanan haruslah mengintegrasikan data-data lainnya seperti aspek lingkungan, sosial dan ekonomi. Sehubungan dengan sifat yang dinamis dan kompleksitas dari sumberdaya perikanan, maka ketersediaan data yang akurat dan terpecaya menjadi penting.

Dalam mengembangkan sistem informasi perikanan, maka beberapa kegiatan yang dapat dilaksanakan adalah (1) penyempurnaan metode dan kerangka survei statistik perikanan, (2) penyempurnaan buku pedoman survei statistik perikanan, (3) pengembangan sistem data statistik, (4) pelatihan enumerator dan supervisor pengumpulan data serta pengolah data, (5) uji coba pedoman survei statistik perikanan dan (6) sosialisasi sistem data statistik.

\section{DAFTAR PUSTAKA}

Barus, Baba., dan U.S. Wiradisastra., 2000. Sistem Informasi Geografi; Sarana Manajemen Sumberdaya. Laboraturium Pengindraan Jauh dan Kartografi Jurusan Tanah Fakultas Pertanian IPB. Bogor.

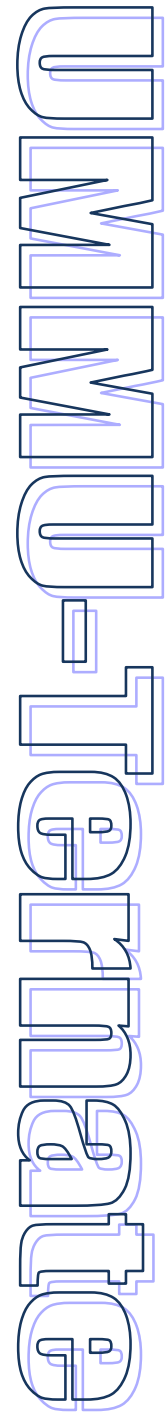

Burch, J.G., F.R.Strater, and G.Grundnitski. 1979. Information Systems: Theory And Practice. Wiley \& Sons. News York, USA.

Cholik, F. 2000. Kondisi Perikanan Peluang dan Tantangan. Makalah disajikan pada Seminar Nasional dan Talk Show Marine Techno and Fisheries 2000, Jakarta. 8 - 9 Agustus.

Dahuri, R., J.Rais, S.P. Ginting, dan M.J. Sitepu. 2001. Pengelolaan Sumberdaya Pesisir dan Lautan Secara Terpadu. Pradnya Paramita. Jakarta.

Damardjati, D.S., I.G. Ismail dan T. Alihamsyah, 2000. Pengembangan pertanian berkelanjutan di lahan rawa untuk mendukung ketahanan pangan dan pengembangan agribisnis : konsepsi dan strategi pengembangannya. Dalam Prosiding Seminar Nasional Penelitian dan Pengembangan Pertanian di Lahan Rawa. Cipayung, 25-27 Juli 2000.

DKP., 2008. Urgensi RUU Pengelolaan Wilayah Pesisir dan Pulau-pulau Kecil. Artikel on-line Dinas Kelautan dan Perikanan.

Dahuri, R. 2000. Pengembangan IPTEK Kelautan Untuk Pengelolaan Sumberdaya Kelautan. Dalam Prosiding Seminar Kelautan 2000 Peranan Ilmu Ilmiah Dalam Eksplorasi, Eksploitasi, dan Pelestarian Sumber Daya Laut. Pusat Studi Kelautan FMIPA Universitas Indonesia bekerjasama dengan Puslitbang Oseanologi LIPI. Jakarta, Indonesia. hal 33 - 48.

Davis, G.B. 1999. Kerangka Dasar Sistem Informasi Manajemen Bagian I Pengantar. Pustaka Binaman Pressindo. Jakarta, Indonesia.

Jogiyanto, H.M. 1992. Analisis dan Desain Sistem Informasi: Pendekatan Tersruktur Teori dan Praktek Aplikasi Bisnis. Andi Yogyakarta. 887 hal.

KOMNAS KAJIS KANLAUT (Komisi Nasional Pengkajian Sumber Daya Perikanan Laut). 1998. Potensi, Pemanfaatan dan Peluang Pengembangan Sumber Daya Ikan Laut di Perairan Indonesia. Puslitbang Oseanologi LIPI. Jakarta, Indonesia. 251 hal.

NOAA., 2002. Environmental Sensitivity Index Guidelines, Version 3.0. NOAA Technical Memorandum NOS OR\&R 11. Office of Response and Restoration, National Oceanic and Atmospheric Administration.

Pasaribu, B.P. 2000. Pengembangan Riset dan Teknologi Pada Sektor Kelautan dan Perikanan. Makalah disajikan pada Seminar Nasional dan Talk Show Marine Techno and Fisheries 2000, Jakarta. 8 - 9 Agustus.

Pharmasetiawan, B., R.Mastra, B.P.Resosudarmo, S.Hakim Ad Dairi dan Y.Budiyanto. 2000. Sistim Informasi Kelautan Terpadu, Sebuah Sumbangan Konsep Untuk Pembangunan Pusat Data Kelautan di Indonesia. Makalah disajikan pada Seminar Nasional dan Talk Show Marine Techno and Fisheries 2000, Jakarta. 8 - 9 Agustus. 
Sari, T.E.Y. 2000. Pengembangan Sistem Informasi Perikanan di Perairan Bengkalis Propinsi Riau. M.Si Thesis Teknologi Kelautan. Institut Pertanian Bogor, Bogor, Indonesia.

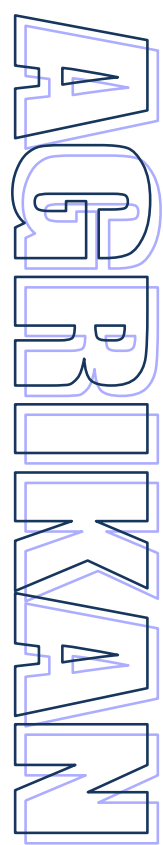

Supriharyono, M.S. 2000. Pelestarian dan Penelolaan Sumberdaya Alam di Wilayah Pesisir Tropis.

PT. Gramedia Pustaka Utama. Jakarta.

Susana, T. et al., 2004. Laporan Akhir Penelitian Perairan untuk Mendukung Pemanfaatan dan Pengendalian Sumberdaya Perairan Banteng. Proyek Penelitian IPTEK Kelautan Puslit Oseanografi-LIPI, Jakarta.

Tahir, A. 2000. Kebutuhan Data dan Informasi Bagi Perencanaan Pembangunan Perikanan. Warta Pesisir dan Lautan II (04): 8-10. Pusat Kajian Sumberdaya Pesisir dan Lautan, Institut Pertanian Bogor, Bogor, Indonesia.

Yahya., 2007. Disain Sistem Perencanaan dan Pengembangan Perikanan Tangkap di Kabupaten Kupan Nusa Tenggara Timur. Thesis S2 (tidak di Publikasikan). Institut Pertanian Bogor (IPB). Bogor.

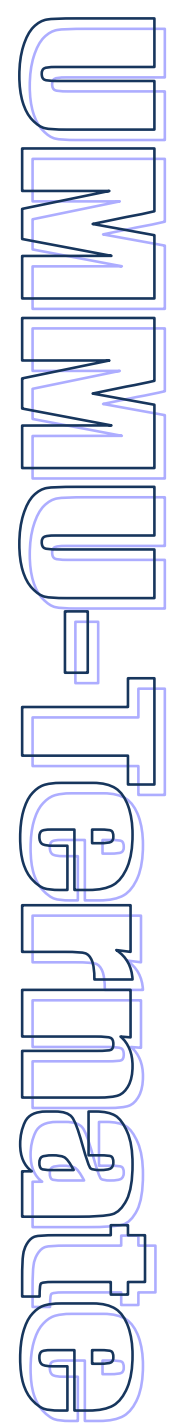

